KAIROS ELT JOURNAL, Vol. 2, No. 1, April 2018

Copyright@2018, ISSN: 2580-4278

\title{
AN ANALYSIS ON THE ERRORS IN USING SIMPLE PAST TENSE MADE BY STUDENTS AT CLASS VIII-C IN SMP TRISAKTI I MEDAN
}

\author{
Roganti Situmorang, Erikson Saragih, Karisma E. Tarigan \\ Catholic University of Saint Thomas
}

\begin{abstract}
This research is aimed to analysis on the errors in using simple past tense made by students at class VIII in SMP Trisakti I Medan. The subject of this research of the eighth grade students of SMP Trisakti I Medan. The method used in this study was descriptive analysis method to describe students' errors and analyze the data by using formula: $P=\frac{F}{N} \times \mathbf{x} 100 \%, \mathrm{P}=$ percentage, $\mathrm{F}=$ Frequency of error made, $\mathrm{N}=$ Total of students' errors. The data was taken from the test: it was written test. The result of the errors analysis process showed that students' committed error into four types: omission, addition, misformation, and misordering. From the frequency of each error types, showed that there are 218 errors made by the students.the most frequent error made by students is Misformation which consists of 160 errors or 73,3\%, it is followed by omission with 32 errors or $14,7 \%$. The next is addition which consists of 15 errors or $6,7 \%$. And the last is misordering with 11 errors or $5 \%$.
\end{abstract}

Keywords : error, error analysis, simple past tense

\section{INTRODUCTION}

Nowdays, many people want to learn English for many reasons. For instance, the students want to learn English because it is the school curriculum. They have to learn it whether they like or not. In different case, some people want to study English because it offers a chance for advancement in their professional lives. In addition, many people want to learn it because they live in target language community, so they have to learn it in order they can communicate with the others.

All people in this world need language to communicate. Some countries use English as a first language and a second language while others use it as a foreign language. While in Indonesia, English used as a foreign language which is taught in schools and it has been taught in every level of school education. In fact, English becomes a compulsory subject which is learn by the students.

Many people argue that to describe the subject matter is very difficult because in Indonesia, English is a foreign language which is taught in elementary school, junior high school and senior high school. for many years ago the material of English is emphasized in the structure of language, the students are expected to be able to recall the pattern of tenses. It too hard for the students, and it makes the students lazy to learn English.

Therefore, English has been an important part of the school curiculum, which is learnt as the main subject by the indonesian students to develop technology, science and culture. To achieve it, the indonesian students must be able to master the four skills English; they are listening, reading, speaking and writing, and also components such as grammar and vocabulary, pronunciation.

Learning English language is not as a simple as we taught because there is a set of rules that must be learnt which is called grammar. Grammar is one of the English components which are taught to every language learner. It has an very important role in understanding the English language. Without proper knowledge of grammar the students will find many problems to build up the sentences and express their ideas for communication activities. But if they have a good 
grammar. They will be confidence in speaking and writing English and they are also able to use the language correctly and clearly.

In learning English, students are required to master grammar. By mastering grammar, they can build up the sentences and express their ideas for communication activities. Besides, they can also improve their ability in understanding reading text. Those are some advantages the students will get through learning English grammar. Meanwhile, English grammar is different from indonesian.

One of aspects of grammar is tense. In making a sentence in English either writen or spoken, tense plays a very important role. In English, each sentence always contains tense. Lock pointed, tense is different form of a verb that indicate distinctions in time. There are many kinds of tense such as a simple present tense, simple past tense, present perfect tense, present continious tense. From those tense, some students find some difficulties in understanding simple past tense. To understand simple past tense is not easy especially in indonesian students because the translation of these tenses have no differences in indonesian.

According to Baker in (Jabbary, 2013) Tense is a grammatical category which involves changing thr form of the verb to reflect the location of an even in time. The usual distinction is between past, present, and future. According to Jabbary (2013) Tense is the grammatical category which correlates with distinctions of time. Every language is capable of expressing events happening in different times. Differentiating between time and tense in language is far from trivial. It has proved to play an important part in language learning and translation.

Therefore, tenses is considered as one of difficult materials when students learn grammar. It is proved by some researchers who studied about tenses. As mentioned in some studies on "an error analysis of forming sentence to simple past tense". There are many errors and mistake in learning english tense but making errors and mistake is normal and unavoidable.

According to Azar (1989:25) simple past is used to talk about activities or situations thet began and ended in the past. For example: I met her yesterday. In both sentences, the meeting took place in the past, but in the former one the time is specified "Yesterday". The simple past may be used with habitual or iterative meaning. Example: I saw her every day. However, there is a separate habitual aspect in English (though only in the past tenses) with the construction used to + inf. Example: I used to see her every day.

According the writer's experience, the students usually make errors on tense usage in the verb form and the use of time signal. The students sometimes do not understand when the verb form will be used whether in past. Here are some mistakes that are often made by the students.

a: Did you study English yesterday?

b: Yes, I study English yesterday.

The sentences above are incorrect. In the second sentence, the students do not know if very often the simple past ends in- ed (regular verb). This error happens because they do not know the usage of simple past tense. The students very often forget to changes study become studied. The writer thinks that this problem happens because there is no verb agreement and tense marker in Indonesian. If the students do not understand the tense well, the students can break the language use. Indeed, it causes misunderstanding in communication. Therefore, it needs an error analysis to correct the error.

Error analysis is important in language learning process because it can help teacher to know the strenght and weaknesses of the students. It can also improve teachers' effectiveness in teaching. For the students, it help them to reduce the errors and improve their abilities in learning target language. Error analysis gives some advantages to the teachers and students. It can help them to achieve the goal of language learning process. According to Corder (1981 : 45) all learner make mistake, error analysis help the learner verify how far he has progessed and what remains to be learned. It is an indispensable devide for the learner to learn. 
The researches have been conducted in relation to this study. Inayatul (2014) entitled An Analysis on Student's errors in understanding Simple Past Tense .at The fisrt Grede Students of SMK Dua Mei Ciputat 4 Bekasi. The result of the errors analysis process showed that students comitted error into four type: omission, addition, misformation, misordering. From the frequency of each error types, misformation was the error which most frequently produced by the students. It took $71.09 \%$ of the total errors. Moreove, $15.94 \%$ errors fell into omission and $11.30 \%$ error fell into addition. For misordering, it only took $1.67 \%$.

Based on the problem descriptions above, the writer research this study with to "An Analysis on Students Error in Using Simple Past Tense at SMP Trisakti I Medan". The writer has a reason why the writer chose this topic in the school SMP Trisakti I Medan as the location of the research is: based on the researchers knowledge, this kind of research has never been conducted at this school.

\section{REVIEW OF LITERATURE}

\section{Error}

An error is a noticeable deviation from the adult grammar of a native speaker, reflecting the interlanguage competence of the learner, stated by (Brown 1980:165). Error reveals the portion of the learner's competence in the target language. When the students write in english, most of them are potential in making errors. It something unavoidable since it is a natural process of language learning. Error is related to the students knowledge about the target language.

In studying errors, it is also needed to distinguish error with mistake. Error and mistake are different. According to Brown (1980: 165) a mistake refers to a performance error that is either a random quess or a "slip". In that it is a failure to utilize a known system correctly. All people make mistakes, in both native and second language situations. Native speakers are normally capable of recognizing and correcting such "lapses" or mistakes, which are not the result of a deficiency in competence but the result of some sort of breakdown or imperfection in the process of producing speech. These hesitations, slips of the tounge, random ungrammaticalities, and other performance lapses in native speaker production also occur in second language speech.

James (1996:80 ) stated that errors cannot be self corrected until further relevant input has been provided and converted into intake by the learners, whereas, mistakes can only be corrected by their deviance is pointed out to him or her.

So, from several statements above, it can be concluded that error is the failure of the learners in using the appropriate rule of the language, which will help us to see how learners process the target language and develop underlying system of rules. Error do not need to be seen as a sign of failure because learners use errors as a tool to acquire the target language. Error and mistake are not the same. Errors happen because the learner makes the unacceptable and inappropriate linguistic from that has been regarded as norm in linguistic.

Errors occur because of the learners lack and weakness in understanding the pattern of the linguistic they cannot the mistake himself. Mistakes are caused by temporally lapses of memory, confusion, slips of the tongue.

\section{The Classification of Errors}

Dulay et.al in (James 1996:106) proposes the surface strategy taxanomy. Surface strategy taxanomy highlughts the ways surface structures are altered. Learners may omit necessary items or add unnecessary ones; they may misform items or misorder them. The writer have noticed, however that surface elements of a language are altered in specific and systematic ways which we inemerated briefly at the beginning of this chapter. 
Analyzing errors from a surface strategy perspective holds much promise for researchers concerned with identifying cognitive processes that underlie the learner's reconstruction of the new language. It also makes us aware that learner's errors are based on some logic. They are not the result of laziness or sloopy thinking, but of the learners' use of interim principles to produce a new language. This formulation would imply that he or she knew the correct from all along, in which case he or she would not have produced an error in the first place.

\section{1) Omission}

Omission error occur when an element of the sentence that should be presented is omitted or by the absence of an item that must appear in a well formed utterance, and it often occurs in form of morphemes. There are two mains types of morphemes: lexical morphemes and grammatical morphemes. Lexical morphemes consist of referential meaning of the sentence such as: noun, adverb, adjective and verb in sentence. However, grammatical morphemes include noun and verb inflections, and play a minor role in conveying the meaning of the sentence.

For example:

1) We will taken our exam. The sentence must be "We will have taken our exam".

2) I sleepy. From this sentence the students omitted to be "was" because they were influenced by their mother tounge and translated the sentence word by word. And the correct sentence should be "Iwas sleepy".

3) She were angry. The students failed to choose the correct to be that should be "was" because "was" used for the subject I-She-He-It in simple past. And the correct sentence should be "She was angry".

\section{2) Addition}

Addition errors are the opposite of omissions. They are characterized by the presence of an item which must not appear in a well formed utterance. Addition errors usually occur when the learner has already acquired some target language rules. Based on the explanation for this type of error, the subtypes are as follows:

a. Regularization, which involves overlooking exceptions and spreading rules to domains where they do not apply. For example producing the regular buyed for bought. And also such as, the verb eat not became eated it must be ate.

b. Double marking is defined as failure to delete certain items which are required in some liguistic constructions. A typical result is an english sentence having two negators or two tense markers instead of one. Here is an example: he doesn't know's me contains a redundant third person-s on the main verb know, redundant because the auxiliary do already carries that marker.

For example: he doesn't know's my name, it must be he doesn't know my name.

c. The third category of addition error is simple addition, which caters for all additions not describable as double markings or regularizations. No a particular features characterize simple additions. For example: I call Rudy last night. The error happen in sentence because the students failed to select the correct verb of "call" in past tense. It should be called.

\section{3) Misformation}

Misformation errors are chararacterized by the use of the wrong from of the morpheme or structure. Usually in misformation errors, the learners supply some incorrect uterances. For example: learners form the past tense form of "eat" and write as "eated". These are not randomly commited. For example: The dog eated the chicken, this sentence should be the dog ate the chicken.

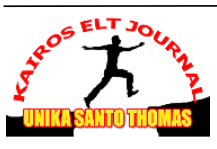




\section{4) Misordering}

Misordering errors are characterized by the incorrect placement of a morpheme or group of morphemes in an utterance. Misordering errors occur when a sentence which its order in incorrect. The sentence can be right in presented elements, but wrongly sequenced. For example:

1) You did meet her yesterday?, this sentence can be formed in a simple questions Did you meet her yesterday?.

2) She was in class yesterday? In this sentence, the students failed to form interrogative sentence of simple past tense because they did not understand well about past tense." because the formula of past tense of BE is: Was/Were $+\mathbf{S}+\mathbf{V 1}$. So the correct the sentence is "Was she in class yesterday?".

\section{The Sources of Errors}

To enumerate all possible sources of second language errors would be an impossible task, for there are surely hundreds of such sources. According to Brown (2006:23) distinguishes the sources of errors into four. They are Interlingual Transfer, Intralingual Transfer, Context of Learning, and Communication Strategies.

\section{Interlingual Transfer}

Interlingual transfer is a significant source of error for all learners. The beginning stages of learning a second language are especially vulnerable to interlingual transfer from the native language, or interference. In these stages, before the system of the second language is familiar, the native language is the only previous linguistics system upon which the learner can draw. We have all heard English learners sat "sheep" for"ship", or "the book of jack" instead of "jack's book". Interlingual errors occur because of the interference of the learners' mother tongue into the target language.

\section{Intralingual Transfer}

Intralingual transfer is a major factor in a second language learning. This error occur when learners under go progress in the second language and their previous experience and their existing sub sumers begin to include structures within the target language it self. Intralingual error happens in the target language it self.

\section{Contex of Learning}

"Contex" refers to the classroom with its teacher and its materials in the case of school learning or the social situation in the case of untutored second language learning. In a classroom context the teacher or the text book can lead the learner to make faulty hypotheses about the language. Students often make errors because of misleading explanation from the teacher, faulty presentation of a stucture or word in a textbook, or even because of a pattern that was rotely memorized in a drill but improperly contetualized.

\section{Communication Strategies}

Communication stategies were defined and related to learning styles. Learners obviously use production strategies in order to enchance getting their messages across. But at times these techniques can themselves bocome a source of error.

\section{Causes of Errors}

Hasyim in ( Norrish 1983: 21) classifies causes of error into three types that is carelessness, first language interference, and translation. The three types of causes of error will be discussed briefly below:

1. Carelessness 
Carelessness is often closely related to lack of motivation. Many teachers will admit it is not always the students fault if he loses interest, perhaps the materials and /or style of presentation do not suit him.

2. First Language

That learning a language (a mother tounge of a foreign language) is a matter of habit formation. When someone tries to learn new habits the old ones will interfere the new ones. This cause of error is called first language interference.

3. Translation

Translation is one of the causes of error. This happens because a student translates his first language sentence or idiomatic expression into the target language word by word. Thus is probably the most common cause of error.

\section{Error Analysis}

The fact that learners do make errors and that these errors can be observed, analyzed, and classfied to reveal something of the system operating whitin the learner, led to a surge of study of learners' errors, called error analysis." Stated by Brown (1980:166). Error analysis became distinguished from constrastive analysisby its examination of errors attributable to all possible sources, not just those which result from negative transfer of the negative language. Error analysis easily superseded contrastive analysis, as we discovered that only some of the errors a learner make are attributable to mother tongue, that learners do not actually make the all errors that constractive analysis predicted they should, and that learners from disperate language backgrounds tend to make similar errors in learning one target language.

According to Corder (1981: 45) error analysis is the study of analysis of the error made by the second of foreign language learners to predict the errors of the difficulties in learning foreign language. Error analysis may be carried out in order to: (a) Find out how well someone knows a language, (b) find out how a person learns a language and (c) obtain information on common dificulties in language learning, as an aid in teaching or in the preparation of teaching materials. This definition stresses the functions of error analysis.

According to James (1996:1) error analysis is the process of determining the incidence, nature, causes and consequences of unsuccessful language. The three definitions above clarify that error analysis is an activity to identify, classify and interpreted or describe the errors made by someone in speaking or in writing and it is carried out to obtain information on common difficluties faced by someone in speaking or in writing english sentence.

\section{Procedure of Error Analysis}

In the language teaching, the teacher must analyze the error that the students made. According to Brown $(1980: 167)$ procedures of error analysis have two types namely:

1. Identifying Errors

The first step in the process of analysis is the identification and description of errors. The identification of error involves a comparison between what the learner has produced and what a native speaker counter part would produce in the same context. If the native language of the learner is know, the model indicates using translation as a possible indicator or native language interference as the source of error.

2. Describing Errors

The descriptions of error involves specifying how the form by the learner differ from target form. For purpose of analysis, errors are usually classified according to language level (whatever an error is phonological, morphological, and syintactic). General linguistic category (e.g: auxiliary system, passive sentence, negative constructions), or more specific linguistic elements (e.g: articles, prepositions, verb form). 


\section{Tenses}

There are many defenitions of tense. According to Jabbary (2013) tense is the grammatical category which correlates with distinctions of time. Therefore, tenses is considered as one of difficult materials when students learn grammar. It is proved by some researchers who studied about tenses. According to Swan (1980:604) tense are formed either by changing the verb (e.g: know, knew, known and work, worked, worked) or by adding auxiliary verb (e.g: will know, had worked). Based on the statement above, the writer concludes that tense is a verb form or series of verb form used to express a time relation, and tense refers to the time of the situation realiting to the situation of the utterance.

\section{The Types of Tense}

Tenses is used to show the relations between the action or state described by the verb, and the time, which is reflected in the form of the verb. According to Azar (1989: 187) There are three basic tense in english : the present tense, the past tense, and the future tense.

1. The Present Tense

The present tense have four types namely: simple present tense, present continious tense, present perfect tense, present perfect continious tense.

2. Past Tense

The past tense have four types namely: simple past tense, past continious tense, past perfect tense, past perfect continious tense.

3. Future Tense

Future tense have four types namely : simple future tense, future tense continious tense, future perfect tense, future perfect continious tense.

Based on the statement above, the writer will focus on "simple past tense".

\section{The Simple Past Tense}

According to Azar ( 1989: 25) the simple past is used to talk about activities or situations that began and ended in the past. The simple past is used to talk about an activity or situation that began and ended at a particular time in the past (e.g., yesterday, last night, two days ago, in 1999). For example: I slept for eight hours last night. and the simple past verbs are formed by adding -ed to verb. For example: Mary walked downtown yesterday.

Based the statement above the writer conclude the simple past is one if the tenses we use to refer to completed events, states or actions. We choose the simple past when we consider that the event, state or action took place within a finished period of time, such as last week, at the weekend, etc.

\section{The Form of Simple Past Tense}

Verb used in simple past tense is the past form of verb. There are two types of verb, regular verb and irregular verb. According to Azar (1989:26) that in simple past tense, a regular past form ends in -ed, some verb have an BE past form. We use did and also were and was in negatives and questions. The formula of simple past tense consist of three parts: affirmative, negative, and interrogative.

\section{Form of Simple Past Tense Regular Verb}

Payne (2011:411) classifies type of simple past tense as follows:

1) The first type (affirmative) of the simple past in regular verb form used the formula is: $\mathbf{S}+\mathbf{V} \mathbf{2}+\mathbf{O}+$ Adverbs. For example : She watched movies last night. From the example it can be seen that the form is used regular verb added-ed in the end verb. 
2) The second type, the negative formula of simple past tense in regular is: $\mathbf{S}+\boldsymbol{d i d}$ not + $\mathbf{V 1}+\mathbf{O}+$ Adverbs. For example : She did not watch movie last night. Based on the example, it can be seen that the verb in negative form use the simple form ( V1 ), then te use of did not is before the main verb.

3) The last type of formula of simple past tense in regular verb is interrogative. The formula is : did/ didn't $+\mathbf{S}+\mathbf{V 1}+\mathbf{O}+$ Adverbs? For example: Did she watch movie last night? and Did not the play game this morning? The example above show that in the interrogative form, the verb used is V1, in other words there is no ending -ed in the verb in question form.

According to Azar (1989:26) that in simple past tense, a regular past form ends in -ed, and we use did in negatives and questions. The following table shows the example about regular form ends in-ed and negative did not (didn't) and question did.

Form of simple past regular verb

Statement I-You-She-He-It-We-They worked yesterday.

Negative I-You-She-He-It-We-They did not (didn't) work yesterday.

Questions Did I-You-She-He-It-We-They work yesterday?

Short answer Yes, I-You-She-He-It-We-They did.

No, I-You-She-He-It-We-They did't.

\section{Form of Simple Past in Irregular Verb}

In the irregular verbs, there is no an -ed ending in the past form. They have different ways in changing past form. As the regular verb, the irregular verb follow the same pattern in afirmative, negative, and interrogative. As the statement above that irregular verbs the pattern of affirmative, negative, and interrogative. Are same with regular verbs, the explanation will explain more detail about the pattern.

1) Affirmative

$\mathrm{S}+\operatorname{Verb2}+\ldots$

Example :

- I bought some foods.

- She got and and accident last night

2) Negative

S + did not + Verb $1+\ldots$

Example:

- I did not meet her after lunch yesterday.

- She did not get an accident last night.

3) Interrogative

Did/did not + S + Verb $1+\ldots$

Example :

- Did You meet her yesterday? Yes, I did / No, I didn't.

- Did She get an accident last night? Yes, She did / No. She didn't.

- Did They go to the concert? Yes, They did / No, They didn't

\section{Form of simple past tense BE}

The following table shows the example about BE form was if we use the subject I-SheHe-It and were if we use the subject You-We-They.

Form of simple past BE

Statement I-She-He-It was in class yesterday.

We-You-They were in class yesterday.

Negative I-She-He-It was not (wasn't) in class yesterday. 
KAIROS ELT JOURNAL, Vol. 2, No. 1, April 2018

Copyright@2018, ISSN: 2580-4278

$\begin{array}{ll} & \text { We-You-They were not (weren't) in class yesterday. } \\ \text { Questions } & \text { Was I-She-He-It in class yesterday? } \\ & \text { Were We-You-They in class yesterday? } \\ \text { Short answer } & \text { Yes, I-She-He-It was Yes, We-You-They were. } \\ & \text { No, I-She-He-It wasn't No, We-You-They weren't }\end{array}$

Based the explanation of the statement above, the writer conclude that regular verbs have their clear rules, but the irregular verbs don't have the rules, but they can be found in the list of irregular verbs or dictionary. When you unsure about the form of the verb, you can check the following list of irregular verbs, or you can check a dictionary, which give the principal parts of irregular verbs.

The examples below show the rules of statement with simple past tense.

1) We listened to music after dinner.

2) The teacher taught the student in the class yesterday.

The examples above show the rules of the regular and irregular verb. The first example uses the regular verb "listened". It easy to identify regular verb. As the explanation before, the regular verb can be known by the endiing of the verb: suffix -ed. The second example uses the irregular verb, "taught" . it is quite hard to identify the irregular verb because the form of irregular verb cannot be predicted. It is needed to see the list of irregular verb on the dictionary to know about it. If the verb is irregular, the dictionary will list the pricipal for you. If there are no principal parts given, form the past and past participle using the regular method. On the other word, if the dictionary can't show the principal or form of the irregular verbs, the principal of regular verbs can be used with adding - ed at the end of the verbs.

In the negative simple past tense statement, the verbs can be added by "didn't or did $n o t$ " before the simple form of the main verbs. The examples of negative form of simple past tense below, explain the rules clearer.

- She didn't get an accident last night.

- I did not study last night.

The examples above show the rules of the negative past tense satement. There are didn't before the simple form of the main verb, get and study. the past tense verbis not used in writing negative past tense statement because to indicate the statement is past tense, it is marked by didn't.

Beside the irregular verbs, there is also irregular be."the only English verb with more than five form is be, the most irregular of our irregular verbs. It is also the only one with three forms for present tense (am, is, are) and two for simple past tense (was, were)". The verb be in the simple past tense only has two forms; they are was and were. Was for the singular, and were for the plural.

There are many changes in spelling rules of the simple past that should be known be everyone. Spelling rules for the simple past tense verbs regular verb:

1. If a simple form a verb ends in- $y$ after a consonant, change the $-y$ to $i$ and add $-e d$. Examples: try / tried, carry / carried, dry / dried.

2. If the simple past tense for of one syllable verbs ends in a consonant + a vowel $+a$ consonant, double the consonant and add - ed. Example: plan / planned. Exception: do not double final $\mathrm{w}, \mathrm{x}$, or $\mathrm{y}$. (example: row / rowed)

3. If the simple form of a two syllable verbs ends in a consonant + a vowel + a consonant, double the final consonant only if the last syllable is stressed.

Example: permit / permitted.

4. If the simple form a verb ends in $-e$ and only $-d$. Example: tie / tied.

5. Add -ed to the simple form af all other regular verbs. Example: want / wanted. 
Beside the rules of the verbs (regular and irregular verbs), there are other rules that should be known, one of them is spelling rules for the simple past tense of regular verb. The table shows that every verb in the regular verb has different spelling, and it depends on the ending sound of the verb whether the verbs ending by consonant or vowel. They have different rules.

Expression of past time is also needed to specify the time in the past when an action was completed. "we often use an expression such as last week, at the weekend, in 1993, 3 years ago, or when we were on holiday to make it clear that the period of time is finished".

\section{RESEARCH METHOD}

In this research, the writer use approach of this study is qualitative research. Because the writer take place in the real situation about social phenomena. Qualitative research is an approach to social science research that emphasizes understanding the subject point of view, stated by Anderson (1998:126). Natural means that qualitative research is done in the real setting as a direct source of data. The writer comes and spend the time in the class, or other learning place educational concern.

The research method of this study is descriptive research. It is a statistic that organizes and analyzes the data, so that can give the descriptive about the phenomenon and the situation which exist at the time of the study. The data collected take the form words or picture rather than the numbers. The writer results of the research contain quotations from the data to ilustrate and subtantiate the presentation.

The research design of this study is case study. The writer chose this design because the writer chooses the possible places and the pupils as a subject of the resource of the data. Case study is a detailed examination of one setting, or a single subject, a single depository of documents, or a particular events, stated by (Ari et.al 1962:295).

\section{DATA ANALYSIS \\ The Description of the Data}

In this research, the data were taken from 30 students of SMP TRISAKTI 1 MEDAN. The data collected in this research were the students' answer sheet about the simple past tense. The writer identified all occurrences of errors and classified them using Dulay's surface strategy taxonomy, namely: Addition, Omission, Misformation, Misordering.

\section{The Result of Interview}

In this interview, the writer did interview after the writer collect the test essay composition about last holiday. The writer asked four (4 ) questions. The first question talked about the method which was used in teaching simple past tense (see appendix 1a no 1). The teacher gave basic explanation and task about the simple past tense, after that she explained about the usage of the simple past tense.

The second questions talked about the textbook which was used in teaching and learning process in the class (see appendix 1a no 2). According to the teacher, the textbook was good enough for helping the students in learning simple past tense.

The third questions talked about the students difficulties in teaching simple past tense (see appendix 1a no 3). According to the teacher, the most difficulty level in using the simple past tense was the students' difficulty in different among to be, verb (regular and irregular). And the last question about the what she did with those diffilculties (see appendix 1a no 4). The teacher gave the students basic explanation about the usage of to be, verb (regular and irregular). And also explained about the new vocabulary. and sometime the teacher to ordered the students to memorize of regular and irregular verbs. 
KAIROS ELT JOURNAL, Vol. 2, No. 1, April 2018

Copyright@ 02018 , ISSN: 2580-4278

Besides interviewing the teacher, the writer also interviewed the students which conducted after they did the test essay compotition about the last holiday. The writer asked the students some questions about problem in learning simple past tense which consist of five (5) questions. The question were divided into two categories. The first category talked about their knowledge and problem about the simple past tense (see appendix $2 \mathrm{a}$ no 1-3). The secon category talked about usage of simple past tense (see appendix 21 no 3-4).

From the students' interview, the writer found the most of the students faced difficulty in determining and using simple past tense form of irregular verb. This difficulty made the students did an error where some of them tended to use simple past tense for every verbs. Beside the simple past tense form, they also got difficulty on determining irregular verb, so they applied reggular pattern, by edding-ed, instead of regular pattern. The errors occured because they did not pay fully attention to the teacher explainantion and because they did not understand in teacher's explanation.

\section{The Result of Test}

After collecting the data, the errors were analyzed based on procedures explained in Chapter III. After collecting the data, the errors were counted by using table and calculated the number of each error.

Table 1. The Recapitulation of Student's Error

\begin{tabular}{|c|c|c|c|c|c|}
\hline \multirow[b]{2}{*}{ No } & \multirow{2}{*}{\begin{tabular}{|l} 
Students' \\
Initial \\
Name
\end{tabular}} & \multicolumn{4}{|c|}{ Types of Error } \\
\hline & & $\begin{array}{l}\text { Error of } \\
\text { Omission }\end{array}$ & $\begin{array}{ll}\text { Error } & \text { of } \\
\text { Addition } & \\
\end{array}$ & $\begin{array}{l}\text { Error of } \\
\text { Misformation }\end{array}$ & $\begin{array}{l}\text { Error of } \\
\text { Misordering }\end{array}$ \\
\hline 1 & EOG & - & - & 3 & - \\
\hline 2 & KYH & 4 & - & 7 & 2 \\
\hline 3 & VDS & 2 & 1 & 3 & - \\
\hline 4 & DS & 3 & - & 12 & - \\
\hline 5 & NBP & 3 & 1 & 6 & 2 \\
\hline 6 & MP & - & - & 1 & - \\
\hline 7 & JMS & 1 & 1 & 2 & 1 \\
\hline 8 & RCA & - & - & 9 & - \\
\hline 9 & ES & - & - & 4 & - \\
\hline 10 & IMKAS & 3 & - & 1 & - \\
\hline 11 & SAG & - & 2 & 4 & - \\
\hline 12 & CFDB & - & 1 & 2 & - \\
\hline 13 & YP & - & 1 & 11 & - \\
\hline 14 & NAS & 1 & 2 & 1 & - \\
\hline 15 & AN & - & - & 8 & - \\
\hline 16 & MP & 3 & 1 & 7 & - \\
\hline 17 & JS & 3 & - & 11 & 1 \\
\hline 18 & TMOS & - & 1 & 11 & 1 \\
\hline 19 & YN & - & - & 2 & - \\
\hline 20 & APWS & 2 & 1 & 1 & 1 \\
\hline 21 & DNS & - & 1 & 4 & - \\
\hline 22 & LM & 1 & & 2 & - \\
\hline 23 & FP & - & - & 4 & - \\
\hline 24 & CMAS & - & - & 9 & - \\
\hline 25 & ML & 1 & - & 3 & - \\
\hline 26 & OS & 1 & - & 5 & 2 \\
\hline
\end{tabular}


KAIROS ELT JOURNAL, Vol. 2, No. 1, April 2018

Copyright@2018, ISSN: 2580-4278

\begin{tabular}{|l|l|l|l|l|l|}
\hline 27 & ST & 2 & - & 10 & - \\
\hline 28 & YM & - & 1 & 9 & - \\
\hline 29 & ES & 1 & 1 & 6 & 1 \\
\hline 30 & IDS & 1 & - & 2 & - \\
\hline & TOTAL $=\mathbf{2 1 8}$ & $\mathbf{3 2}$ & $\mathbf{1 5}$ & $\mathbf{1 6 0}$ & $\mathbf{1 1}$ \\
\hline
\end{tabular}

Based of the table above, it can be concluded that the total errors of omission is 32 errors, and total errors of addition is 15 errors, the total errors of misformation is 160 errors and the last total errors of misordering is 11 errors. So, the total of the all errors is 218 errors. Misformation is the most frequent errors that done by students of SMP TRISAKTI 1 MEDAN CLASS VIII with the errors is 160 errors.

1. The Error of Omission

2. The Error of Addition

3. The Error of Misformation

4. The Error of Misordering

$$
\begin{aligned}
& =\frac{32}{218} \times 100 \%=14,7 \% \\
& =\frac{15}{218} \times 100 \%=6,7 \% \\
& =\frac{160}{218} \times 100 \%=73,3 \% \\
& =\frac{11}{218} \times 100 \%=5, \%
\end{aligned}
$$

Table 2. The Recapitulation of Error Types, Frequency, and its Percentage

\begin{tabular}{|l|l|l|l|}
\hline NO & TYPES OF ERROR & $\begin{array}{l}\text { FREQUENCY } \\
\text { OF ERRORS }\end{array}$ & $\begin{array}{l}\text { PERCENTAGE } \\
\text { OF ERRORS }\end{array}$ \\
\hline 1 & Error of Omission & $14,7 \%$ & 32 \\
\hline 2 & Error of Addition & $6,7 \%$ & 15 \\
\hline 3 & Error of Misformation & $73,3 \%$ & 160 \\
\hline 4 & Error of Misordering & $5 \%$ & 11 \\
\hline
\end{tabular}

Based on the calculation above, it can be conclude that the total errors of omission are 32 errors or $14,7 \%$, addition are 15 errors or $86,7 \%$, and in misformation are 160 error or $73,3 \%$, and misordering are 11 errors or $5 \%$. From the calculation of the data, misformation is the most frequent errors that done by students of SMP TRISAKTI 1 MEDAN CLASS VIII with the percentage 73,3\%. Moreover, it is followed by omission with percentage 14,7\%, and error in addition $6,7 \%$ and misordering fewer than $5 \%$.

\section{The Analysis of the Data}

The writer analyzed the errors that are taken from the Data Description and calculate them according to the formula as written below:

\section{The Description of Errors}

After identifying the data, the writer analyzed the errors and classified them based on the Surface Taxonomy Categories to know whether these errors involve in omission, addition, misformation and misordering.

\section{The Errors of Omission}

Omission occurs when the learners omitted necessary item of word. There are 32 occurrences or $14,7 \%$ of all students' errors. Some students also committed errors by omitting an item that must appear within a morpheme. For example:

1) *we stop in restaurant seafood. (committed by student 20 )

2) *i and my family arrive in Samosir (committed by students 5)

Suggested correction

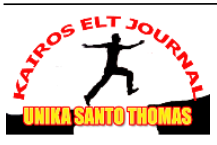


KAIROS ELT JOURNAL, Vol. 2, No. 1, April 2018

Copyright@2018, ISSN: 2580-4278

1) We stopped in restaurant seafood.

2) I and my family arrived in Samosir.

\section{The Errors of Addition}

Addition occurs when the learner added unnecessary item of words. There are 15 occurrence or $6,7 \%$ of all errors occurring in the students' answer sheet. The writer found that the students committed errors by adding unnecessary item in their sentences. For example:

1) *I felt happyed (committed by students 14)

2) *In the morning we back home to Medan cities. (committed by students 29)

3) *one sisters. (committed by students 16)

Suggested correction

1) I felt happy.

2) In the morning we back home to Medan city.

3) One sister.

\section{The Errors of Misformation}

Misformation occurred when the students use the wrong form of morpheme or structure. This type of error is the dominant type of errors which found in this research. There are 160 occurrence or $73,3 \%$ of whole errors occurring in students' answer sheet. For example:

1) *We go to Singapore. (commited by student 17 )

2) *We speak together in the living room. (commited by student 8 )

Suggested correction

1) We went to Singapore.

2) We spoke together in the living room.

\section{The Errors of Misordering}

Misordering is characterized by the incorrect placement morpheme or group of morpheme in an utterance. For example:

1) *Then we went to Hotel Carolina. (commited by student 5)

2) *Home in city Medan. (commited by student 29)

Suggested correction

1) Then we went to Carolina Hotel.

2) Home in Medan city.

\section{Research Findings}

In using simple past tense, it was found that the students made errors and there were four types of error made by them. They were; Omission $(14,7 \%)$, Addition $(6,7 \%)$, Misformation (73,3\%), and Misordering (5\%).

After the data was analyzed, the writer concluded that the dominant type of error made by class VIII-C SMP TRISAKTI I MEDAN in using simple past tense is Misformation.

Here is the fiqure of student's errors based on its modification type of error 


\section{Percentage of Student's Error}

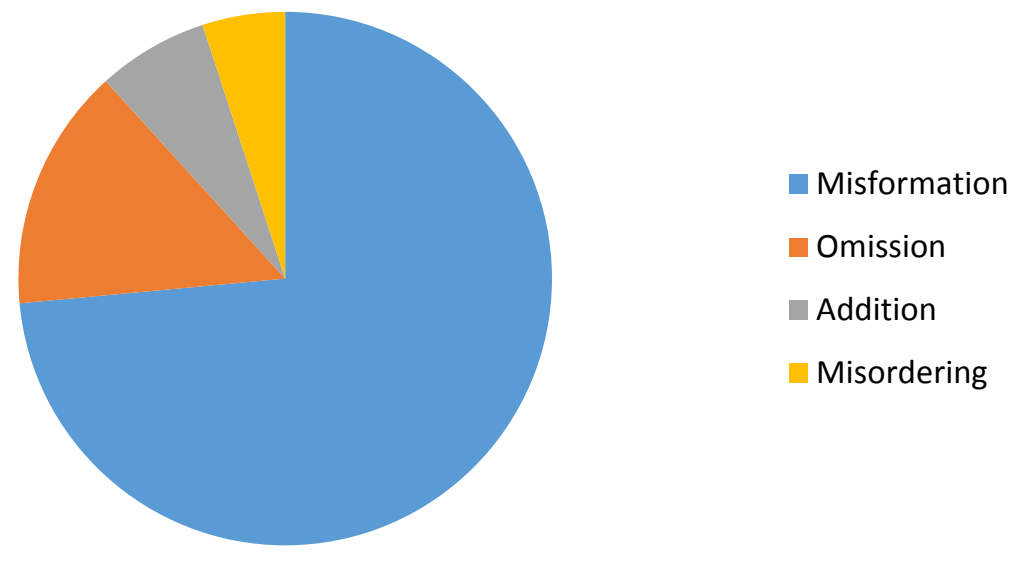

Figure 1. Percentage of Students Error

From the data it could be interpreted that the errors in misformation was the most frequent errors in which the students committed 160 errors or $73,3 \%$, and it was followed by omission that consists of 32 errors or 14,7\%. Then errors in addition consisted of 15 errors or 6,7 \%. Last in errors in Misordering, there are 11 errors or $5 \%$.

\section{CONCLUSIONS}

Based on the research finding found in the data analysis in this study, the conclusions are drawn as following:

1. The types of errors which were made by Class VIII-C at SMP TRISAKTI I MEDAN are: Omission, Addition, Misformation, and Misordering.

2. The dominant types of error made by class VIII-C is error in Misformation it occurs 160 times $(73,3 \%)$.

3. To minimize the errors in using simple past tense at class VIII-C SMP TRISAKTI I MEDAN i have done students should memorize the irregular verb, regular, and auxiliary (was/were) and then apply them to the sentences to increase students achievement.

\section{BIBLIOGRAPHY}

Anderson G. 1998. Fundamentals of Educational Research. Philadelphia : Farmer Press.

Ari,et.al. 1962. Introduction to Research In Education. New York : Appleton.

Azar, Betty S. 1989. Fundamentals of English Grammar. New Jersey : Prentice Hall.

Brown, H Douglas. 1980. Principles of Language Learning and Teaching. New Jersey : Prentice Hall.

Brown, H Douglas. 2006. Principle of Language Learning and Teaching. San Fransisko: San Fransisco State University.

Corder, S Pit. 1981. Error Analysis and Interlanguage. Oxford: Oxford University Press. 
KAIROS ELT JOURNAL, Vol. 2, No. 1, April 2018

Copyright $\odot 2018$, ISSN: 2580-4278

Inayatul. 2014. An Analysis on Student's Errors in Understanding Simple Past Tense at the First Grade Students of SMK Dua Mei Ciputat 4 Bekasi. Sarjana's Thesis, Teacher Training and Education Faculty: State Islamic University. Unpublished.

Jabbary, Mohammad J. 2013. “Time and Tense in Language." International Journal of Linguistics, 5 (5), 243-252.

James, C. 1996. Errors in Language Learning and Use. New York : Wesley Longman.

Norrish, J. 1983. Language Learning and Their errors. London: Macmillan Publisher Ltd.

Payne, E Thomas. 2011. “Understanding English Grammar: a Lingusitic Introduction”. New York: Cambridge University Press.

Putra, N. 2012. “Metode Penelitian Kualitatif Pendidikan” Jakarta: PT Raja Grafindo Persada.

Sudijono A. 2010. “Pengantar Statistik Pendidikan”. Jakarta : PT. Raja Grafindo Persada.

Swan, M. 1980. Practical English Usage. Oxford : Oxford University Press. 